\title{
CRITICA ȘI ESEUL BASARABEAN DIN 2020
}

\author{
Nina CORCINSCHI \\ Institutul de Filologie Română „Bogdan Petriceicu-Hasdeu”(Chișinău)
}

ORCID:https://orcid.org/0000-0002-4903-4477

Rezumat: Anul 2020 a fost prielnic pentru spiritul critic și cel eseistic din R. Moldova. Cărțile scrise la acest compartiment oferă o panorama a gândirii critice actuale, a celor mai moderne perspective de abordare a literaturii. Conceptul „arheul marginii”, de Andrei Țurcanu, oferă o grilă artistică, dar și sociologică de evaluare a rapotului marginii literare cu centrul, adică a literaturii române de pe ambele maluri ale Prutului, în context social, politic, cultural. Cărțile lui Em. Galaicu Păun și Adrian Ciubotaru abordează fenomene culturale actuale (o viziune antropologică a morții, a bolii, a suferinței etc.), autori importanți din literature română și cea universală. Al. Burlacu analizează generațiile 60 și 70 de creație din Basarabia, D. Apetri - fenomenul traducerilor etc. Toate împreună confirmă un proces metaliterar basarabean viabil și racordat la cele mai noi provocări literare românești și europene.

Cuvinte-cheie: critică, eseu literar, proces literar, concept teoretic.

Abstract. Year 2020 was favorable for the critical and essayistic spirit in the Republic of Moldova. The books written in this section offer an overview of current critical thinking, of the most modern perspectives on literature approaching. The concept "arheul marginii", by Andrei T,urcanu, offers an artistic and sociological grid for evaluating the relationship of the literary margin with the centre, i.e. of Romanian literature on both banks of the Prut, in a social, political and cultural context. The books of Emilian Galaicu Păun and Adrian Ciubotaru address current cultural phenomena (an anthropological vision of death, disease, suffering, etc.), important authors in Romanian and universal literature. Alexandru Burlacu analyses the 60th and 70th creation generations in Bessarabia, Dumitru Apetri - the phenomenon of translations, etc. All together they confirm a viable Bessarabian meta-literary process, connected to the latest Romanian and European literary challenges.

Keywords: criticism, literary essay, literary process, theoretical concept.

Anul 2020 a fost prielnic pentru spiritul critic și cel eseistic din R. Moldova. S-au adunat câteva cărți bune, unele chiar foarte bune, oferind o panorama a gândirii critice actuale, a celor mai moderne perspective de abordare a literaturii.

Andrei Țurcanu publică volumul Critice. Arheul Marginii și alte narațiuni (Cartier), în care impune un concept-grilă de analiză a literaturii române din Basarabia: arheul marginii. Acesta reprezintă pentru Andrei T,urcanu „criteriul axiologic, ontologic de raportare multiplă și conexiune a noastră cu lumea și cu timpul, proba de rezistență a artisticului”. Iar artisticul sau 
esteticul se definește, în aria acestei hermeneutici, printr-o raportare complexă la diacronia factorilor sociologici și antropologici. E o abordare care încearcă să pună într-o perspectivă unică mecanismul complicat de interferare a rețelelor de viziune artistică cu cele de mentalitate istorică, socială și de sensibilitate etnică. Urmărită în strânsă legătură cu circumstanțele celor două veacuri de „îmbrăţișare frățească” a Basarabiei de către imperiul de la Răsărit, literatura basarabenilor își dezvăluie un spiritus loci cu notele distinctive și manifestările sale literare (și culturale) specifice (nu însă neromânești sau antiromânești!) în raport cu literatura română de peste Prut. Andrei Țurcanu evocă imaginea câtorva scriitori singulari, Alecu Russo, Bogdan PetriceicuHasdeu, Constantin Stere, Paul Goma și Antonie Plămădeală, care au avut în literatura și cultura română un rol de fermenți și stimulatori ai arheității naționale. Misionari profetici, acești „basarabeni ai marginii” contrapun - cu o intransigență morală și o forță creatoare covârșitoare - Centrului Naţional criteriile absolute ale Patriei Ideale. Atât prin raportările la Centrul imperial, cu efectele pseudomorfice și izomorfice ale acestuia, cât și prin impulsionările Centrului național, arheul marginii, ca expresie a profunzimilor naționale $\mathrm{cu}$ specificările lor locale inerente, vizează constant o transgresiune a localismului, o resuscitare a adâncurilor identitare și, implicit, o ieșire către europenitate.

În Idei și fantasme. Lecturi în hialin (Cartier), Adrian Ciubotaru scrie despre nebunie, boală, erotism, ură, frumos și alte concepte "grele”, care au generat abordări diverse în perimetrul științei și al artei și pe care eseistul le trece printr-un filtru hermeneutic interdisciplinar. Comentariile lui sunt mici tratate de literatură comparată și denotă o deosebită pasiune a autorului pentru speculația filozofică, pentru dezbaterea de idei. Nume mari din literatură și cultură: Umberto Eco, Lliosa, Agamben, în plan românesc - Gabriel Liiceanu, Dan Alexe, Lucian Boia etc. îi prilejuiesc lui Adrian Ciubotaru descinderi spectaculoase în spațiul ideilor. Cele mai savuroase și îmbietoare sunt în această carte textele senzitivității. Autorul ne oferă o plimbare prin bucătăria lui Rabelais, „cel mai mare gastroenterolog literar al tuturor timpurilor”, a lui Cervantes, a lui Flaubert, dar și prin bucătăriile literare românești, ale lui George Călinescu, Calistrat Hogaș. Lista deserturilor e și mai generoasă: instrucțiunile pornesc de la Toma din Aquino, cu Summa theologica, până la gurmanzii Georges Duby, Johan Huizinga, Gilbert Durand etc. Toate aceste „frivolități” senzitive sunt dezvoltate de Adrian Ciubotaru în narațiuni eseistice elegante, pe cât de documentate și erudite, pe atât de ludice și savuroase.

Alexandru Burlacu în Proba esteticului. (Neo)moderniști basarabeni (Gu- 
nivas) propune o hartă sinoptică a stilurilor, temelor, limbajelor, viziunilor artistice ale poeților anilor '60-'70. Poezia șaizecistă impune lirismul de tip evazionist și subversiv exprimat prin figura bufonului, a nebunului, a unui orfeu îngândurat. Acest tip de lirism, la poeții șaptezeciști, se încarcă de ludism și converge în experimentalism (lingvistic) executat cu precauțiune. Cine face trecerea spre „o nouă paradigmă poetică”, optzecistă? 3 poeți - după opinia lui Alexandru Burlacu: Eugen Cioclea, Andrei Țurcanu și Vsevolod Ciornei. Ei propun un altfel de lirism. Un lirism pe dos, ca reacție la versul calofil, ca o strunire a spiritului critic și o diluare a efuziunilor patetice ale unui literaturi încremenite în zodia cumințeniei, a acceptării. Așadar „proba esteticului” reprezintă „o mutație de la est-eticul ardent al reazămului, al preaplinului la esteticul eliberat de sentimentalitate", la poezia imaginarului, a lumilor virtuale, a modurilor poetice". Tabloul celor două generații de creație se conturează din scriitorii reprezentativi, dar și din cei de nişă: Arhip Cibotaru. Emil Loteanu, Pavel Boțu etc., relevanți prin contribuția personală în constituirea unei poetici de grup, cu datele ei particulare, specifice.

Texistențele IV. Ființa poeziei (Gunivas) analizează scrupulos poetici, formule de creație, stiluri și viziuni artistice ale poeților basarabeni. Alexandru Burlacu este criticul de formație academică, al cărui scris oferă nu doar diagnosticul, ci și situarea axiologică precisă, ierarhia sigură de valori.

Mihai Cimpoi continuă seria de studii monografice despre scriitorii târgovișteni, publicând în 2020 un amplu eseu despre Petru Creția, intitulat Petru Creția. Epos, logos, eidos. Eseu monografic (Editura Bibliotheca, Târgoviște). Autorul analizează activitatea de editor și hermeneut a lui Creția, modul în care gânditorul s-a raportat la „fenomenul Eminescu” și la lumea antică, la mari autori, precum Homer, Dante, Shakespeare. Mihai Cimpoi nu ocolește nici microtratatele de etică scrise de Creția și nici lirica sa filozofică. Norii, oglinzi, Poezii, Pasărea Phonix, Fântâni din adâncul mării sunt „creații dominate de i-realism, de rafinament alexandrin, de text mitopo(i)etic ce se supun propriilor legi de elaborare”. Tot la Editura Bibliotheca, Târgoviște, criticul literar publică cartea Titu Maiorescu și lumea noastră postmodernă. Eseuri. În atenția dlui acad. se află fazele receptării lui Maiorescu, modul în care acesta a fost citit de Constantin Noica, „maiorescianismul” ca fenomen modelator și desigur relația Maiorescu - Eminescu. Potrivit lui Mihai Cimpoi, Maiorescu este criticul prin excelență, așa cum Eminescu reprezintă patternul Poetului.

Emilian Galaicu-Păun în Cărțile pe care le-am citit, cărțile care m-au scris (Junimea) propune eseuri savuroase despre scriitori universali și cărți de mare 
impact cultural. Autori-reper, precum Márquez, Cortázar, Vonnegut, Pavić, Ishiguro, Calvino, Hrabal, Kadare, Lee, $\mathrm{Oz}$ etc. servesc drept pretexte pentru narațiuni critice, în care discursul despre literatură este el însuși literatură de cea mai bună calitate.

Arcadie Suceveanu adună în Cu grație printre (pre)texte (Arc) eseuri publicate în Revista literară. În binecunoscutu-i stil percutant și rafinat, eseistul abordează - în eseuri, interviuri, răspunsuri la anchete - subiecte ce țin de lumea literară și culturală din Republica Moldova și Bucovina, precum probleme ale traducerii literare, politizarea scriitorului etc. Un capitol al cărții este dedicat portretelor scriitorilor de ieri și de azi: George Meniuc, Aureliu Busuioc, Ion Druță, Petru Cărare, Nicolae Popa etc.

Eseurile și cronicile lui Dumitru Apetri din Eminescu. Sporind a lumii taină (Știința) se referă la aspecte mai puțin frecventate de exegeza eminescologică: contribuția scriitorilor din Cernăuți la valorificarea creației eminesciene, receptarea estică a poetului, traducerile creației sale în mediul de expresie slavă.

Marcel Gherman în Mireasa Centaurului (Arc) propune eseuri despre literatura fantasy. Elemente de fantastic, suite de referințe culturale formează construcții armonice cu datele noi ale prezentului: jocuri de calculator, precum Death Stranding, desene animate de pe Cartoon Network, de la care se pot învăța „niște lucruri elementare, de negăsit în niciun volum de Heidegger”. Erudiția și imaginația puse pe noi portative ale gândirii critice fac foarte antrenantă călătoria virtuală „de la Mahabharata la computerul-romancier”.

În acest an au fost premiate de Uniunea Scriitorilor din Moldova titlurile semnate de Andrei Țurcanu și Adrian Ciubotaru. Premiate sau doar nominalizate, toate aceste volume confirmă un proces metaliterar basarabean viabil și racordat la cele mai noi provocări literare românești și europene.

Notă: Articolul a fost realizat în cadrul proiectului de cercetare 20.80009.1606.03 Contexte socio-culturale autohtone și interconexiuni europene în creația populară și literatura cultă din Basarabia (sec. XIX până în prezent), Institutul de Filologie Română „Bogdan Petriceicu-Hasdeu” al MECC. 